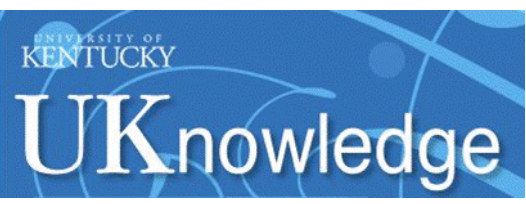

University of Kentucky

UKnowledge

\title{
"Competing Conceptions of Globalization" Revisited: Relocating the Tension Between World-Systems Analysis and Globalization Analysis
}

Thomas Clayton

University of Kentucky, tmclay@uky.edu

Follow this and additional works at: https://uknowledge.uky.edu/lin_facpub

Part of the Economics Commons, International and Comparative Education Commons, and the Political Science Commons

Right click to open a feedback form in a new tab to let us know how this document benefits you.

\section{Repository Citation}

Clayton, Thomas, "'Competing Conceptions of Globalization" Revisited: Relocating the Tension Between World-Systems Analysis and Globalization Analysis" (2004). Linguistics Faculty Publications. 74.

https://uknowledge.uky.edu/lin_facpub/74

This Article is brought to you for free and open access by the Linguistics at UKnowledge. It has been accepted for inclusion in Linguistics Faculty Publications by an authorized administrator of UKnowledge. For more information, please contact UKnowledge@lsv.uky.edu. 
"Competing Conceptions of Globalization" Revisited: Relocating the Tension Between World-Systems Analysis and Globalization Analysis

\author{
Digital Object Identifier (DOI) \\ https://doi.org/10.1086/421180 \\ Notes/Citation Information \\ Published in Comparative Education Review, v. 48, no. 3, p. 274-294. \\ (c) 2004 by the Comparative and International Education Society. All rights reserved. \\ The copyright holder has granted the permission for posting the article here.
}




\title{
“Competing Conceptions of Globalization” Revisited: Relocating the Tension between World-Systems Analysis and Globalization Analysis
}

\author{
THOMAS CLAYTON
}

In recent years, many scholars have become fascinated by a contemporary, multidimensional process that has come to be known as "globalization." Globalization originally described economic developments at the world level. More specifically, scholars invoked the concept in reference to the process of global economic integration and the seemingly inexorable movement toward a single economy and a single division of labor in the world. For Leslie Sklair, globalization thus refers (among other things) to the "emergence of a globalized economy based on new systems of production, finance and consumption." "Terry Boswell and Christopher Chase-Dunn understand the economic dimension of globalization similarly, as the evolution of "transnational sourcing and a single interdependent global economy" facilitated by "foreign investment, information exchange, ... world cultural commercialization, [and] the integration of trade and production." ${ }^{2}$

Beyond economic inquiry, the globalization concept has proved quite useful in exploring other recent world-level processes and developments. Scholars have studied world cultural and political integration, for instance, as dimensions of globalization; it is in such contributions that we encounter references to the "MacDonaldization" or "Americanization" of culture and to the "withering" or "retreat" of the nation-state. ${ }^{3}$ A casual scan through any library database illustrates the ever-more specific applications of the globalization concept to such realms as health policies, music, ethnicity, gender,

\footnotetext{
${ }^{1}$ See Leslie Sklair, "Competing Conceptions of Globalization," Journal of World-Systems Research 5 (Summer 1999): 143-62, quotation on 146, http://www.jwsr.ucr.edu/archive/vol5/number2/html/ sklair/index.html.

${ }^{2}$ Terry Boswell and Christopher Chase-Dunn, The Spiral of Capitalism and Socialism: Toward Global Democracy (Boulder, Colo.: Lynne Reinner, 2000), pp. 33-34.

${ }^{3}$ Widely cited discussions include Arjun Appadurai, Modernity at Large: Cultural Dimensions of Globalization (Minneapolis: University of Minnesota Press, 1996); Jean-Marie Guéhenno, The End of the NationState (Minneapolis: University of Minnesota Press, 1995); Michael Hardt and Antonio Negri, Empire (Cambridge, Mass.: Harvard University Press, 2000); George Ritzer, The McDonaldization of Society (Thousand Oaks, Calif.: Pine Forge Press, 2000); Susan Strange, The Retreat of the State: The Diffusion of Power in the World Economy (Cambridge: Cambridge University Press, 1996).

Comparative Education Review, vol. 48, no. 3.

(c) 2004 by the Comparative and International Education Society. All rights reserved.

0010-4086/2004/4803-0003\$05.00
} 
religion, and the environment. ${ }^{4}$ Applied studies such as these often illustrate a connection to the economic foundations of globalization inquiry. Some scholars explore how their phenomenon of interest (culture, politics, etc.) contributes to the development or workings of the global economy, frequently conceptualized as an exploitative system in which capital moves along a generally north-south axis. Others use global economic integration as a metaphor for the global homogenization of practice-and the concurrent loss of local varieties of practice-related to their phenomenon of interest. Of course, yet others explore the benefits that globalization may bring in relation to these same domains, whether materially or metaphorically. ${ }^{5}$

In the last few years, there has been a virtual explosion of interest in globalization by comparative education scholars. Scholars have produced edited volumes such as Comparative Education: The Dialectic of the Global and the Local, Educational Restructuring in the Context of Globalization and National Policy, Globalization and Education: Critical Perspectives, and Globalization and Education: Integration and Contestation across Cultures. ${ }^{6}$ Special issues of Comparative Education and the Comparative Education Review have been devoted to the topic. ${ }^{7}$ A journal concerned exclusively with globalization and education, Globalisation, Societies and Education, began publication in $2003 .{ }^{8}$ Like scholars in other applied areas, comparative education scholars orient their inquiry both materially and metaphorically in relation to economic research. That

${ }^{4}$ Among the hundreds of books published in the last few years that explore global integration beyond the economic domain, one encounters Jane Bayes and Nayereh Tohidi, eds., Globalization, Gender, and Religion: The Politics of Women's Rights in Catholic and Muslim Contexts (Basingstoke, Hampshire, U.K.: Palgrave, 2001); Stephen Castles, Ethnicity and Globalization: From Migrant Worker to Transnational Citizen (London: Sage, 2000); John Connell and Chris Gibson, Sound Tracks: Popular Music, Identitv, and Place (London: Routledge, 2003); Kelley Lee, Kent Buse, and Suzanne Fustukian, eds., Health Policy in a Globalising World (Cambridge: Cambridge University Press, 2002); Peter Mandaville, Transnational Muslim Politics: Reimagining the Umma (London: Routledge, 2001); Otto Solbrig, Robert Paarlberg, and Francesco Di Castri, eds., Globalization and the Rural Environment (Cambridge, Mass.: Harvard University Press, 2001).

${ }^{5}$ In a balanced discussion of globalization, Gordon Smith and Moisés Naím (Altered States: Globalization, Sovereignty, and Governance [Ottawa: International Development Research Centre, 2000]) attempt to answer the question posed by Nicholas Burbules and Carlos Alberto Torres ("Globalization and Education: An Introduction," in their Globalization and Education: Critical Perspectives [New York: Routledge, 2000], pp. 1-26, quote on p. 17): "Is globalization merely deleterious, or are there positive features associated with its practices and dynamics?" Douglas Kellner similarly works to describe globalization in a way that "overcomes the one-sidedness and ideological biases that permeate most conceptions of this all-embracing and complex phenomenon" ("Globalization and New Social Movements: Lessons for Critical Theory and Pedagogy," in Burbules and Torres, eds., pp. 299-321, quote on p. 301).

${ }^{6}$ Respectively, Robert Arnove and Carlos Alberto Torres, eds., Comparative Education: The Dialectic of the Global and the Local (Lanham, Md.: Rowman \& Littlefield, 1999); Holger Daun, ed., Educational Restructuring in the Context of Globalization and National Policy (New York: RoutledgeFalmer, 2002); Burbules and Torres, eds.; Nelly Stromquist and Karen Monkman, eds., Globalization and Education: Integration and Contestation across Cultures (Lanham, Md.: Rowman \& Littlefield, 2000).

${ }^{7}$ Respectively, Michael Crossley and Peter Jarvis, eds., "Comparative Education for the Twenty-First Century: An International Response," special issue, Comparative Education 37 (November 2001); Martin Carnoy and Diana Rhoten, eds., "The Meanings of Globalization for Educational Change," special issue, Comparative Education Review 46 (February 2002).

${ }^{8}$ Roger Dale and Susan Robertson, eds., Globalisation, Societies and Education (London: Taylor \& Francis). 
is, some examine how education facilitates the flow of capital in the world, while others explore the homogenization of education-and local responses to it, including forms of resistance-at the world level. Susan Robertson, Xavier Bonal, and Roger Dale illustrate both tendencies in their analysis of the education service industry within the World Trade Organization. Under the influence of the General Agreement on Trade in Services, these authors argue, education is being restructured as a commodity "which can be sold in the global marketplace." Among other outcomes of the global commercialization of education, they conclude, may be worldwide convergence related to educational credentials, knowledge, language, and identity. ${ }^{9}$

The recent excitement about globalization in the scholarly community and the general acceptance of globalization as an orienting concept for studies in myriad domains could be seen as an important validation for that group of scholars who have for decades recognized the existence of an integrated world-economy operated by a single division of labor and who have worked diligently to understand how multiple phenomena both effect and are affected by this formation. ${ }^{10}$ I refer of course to world-systems analysts. In addition to those concerned with economic history and trajectory, worldsystems analysts also include those interested in educational systems, policies, and practices. In this latter group, we may place Robert Arnove, whose article "Comparative Education and World Systems Analysis" introduced the concept of the world-system to the field of comparative education, and Mark Ginsburg, whose edited volume Understanding Educational Reform in Global Context was conceptually oriented by world-systems analysis. ${ }^{11}$ I also locate myself in this group; my article, "Beyond Mystification: Reconnecting World-System Theory for Comparative Education," attempted to illustrate the continuing relevance of world-systems analysis for comparative studies in education. ${ }^{12}$

However, the ascendancy of globalization as an orienting concept for economic and other inquiry has not validated world-systems analysis. On the contrary, certain globalization scholars have carefully positioned world-systems analysis as fundamentally different from, and therefore not affirmable by, their own approach, which Roland Robertson elevates to the level of

\footnotetext{
${ }^{9}$ Susan Robertson, Xavier Bonal, and Roger Dale, "GATS and the Education Service Industry: The Politics of Scale and Global Reterritorialization," Comparative Education Review 46 (November 2002): 472-96, quote on 479.

${ }^{10}$ Which is not to say that globalization is universally accepted as an orienting concept for studies in economics or other fields. Important voices speaking against the concept include Paul Hirst and Grahame Thompson, Globalization in Question: The International Economy and the Possibilities of Governance (Cambridge: Polity Press, 1996); and Linda Weiss, The Myth of the Powerless State: Governing the Economy in a Global Era (Cambridge: Polity Press, 1998).

${ }^{11}$ Robert Arnove, "Comparative Education and World Systems Analysis," Comparative Education Review 24 (February 1980): 48-62; Mark Ginsburg, ed., Understanding Educational Reform in Global Context: Economy, Ideology, and the State (New York: Garland, 1991).

${ }^{12}$ Thomas Clayton, "Beyond Mystification: Reconnecting World-System Theory for Comparative Education," Comparative Education Review 42 (November 1998): 479-96.
} 
formal inquiry as "globalization analysis."13 Sklair locates the most important element of this opposition in the contrast between "global" and "international." The central feature of globalization analysis, Sklair argues, "is that many contemporary problems cannot be adequately studied at the level of nation-states, that is, in terms of each country and its inter-national relations, but instead need to be seen in terms of global processes." World-systems theorists, on the other hand, "have tend[ed to understand] the world-economy [as] based on the system of nation-states," thus remaining fundamentally "state centrist" in orientation. ${ }^{14}$

Is Sklair's characterization correct? Does globalization analysis truly offer a different perspective on the integration of the world than world-systems analysis?

In brief, yes and no: globalization analysis does differ from world-systems analysis, though not in the way Sklair identifies. The purpose of the discussion that follows is to define this difference more accurately-to relocate the tension between world-systems analysis and globalization analysis-through a review of 50-plus years of thinking about world interconnectivity. I organize this review temporally, beginning with dependency theory as a response to modernization theory, and then examining how world-systems analysis advanced this earlier conception. Penultimately, I consider the degree to which globalization analysis replicates, and departs from, the world-systems approach. For the most part, I illustrate this history of thinking about international and global integration with reference to economic inquiry. This approach is not intended to suggest economism but to anticipate application. I thus conclude the essay by considering the implications of my findings for comparative education. Conceptualizing the tension between world-systems analysis and globalization as a debate may provide a focus for inquiry that answers the concern raised recently by Carlos Alberto Torres, notably that there is a "lack of concrete empirical research" on globalization in comparative education. ${ }^{15}$

\footnotetext{
${ }^{13}$ Roland Robertson, Globalization: Social Theory and Global Culture (London: Sage, 1992), p. 15. According to Robertson, "globalization analysis and world-systems analysis are rival perspectives" (p. 15).

${ }^{14}$ Sklair, "Competing Conceptions" (n. 1 above), pp. 144, 150-51. Roger Burbach and William Robinson similarly characterize world-systems analysts as "believ[ing] in the continued primacy of the nation-state" ("The Fin de Siecle Debate: Globalization as Epochal Shift," Science and Society 63 [Spring 1999]: 10-39, quote on 12). Sklair also criticizes world-systems analysis as "economistic," a reference to its initial economic focus ("Competing Conceptions," p. 150). However, as Maximilian Forte correctly points out, world-systems analysis has been applied well beyond this initial area of inquiry-including, of course, to the comparative study of educational systems, policies, and practices. It may still be possible to "accuse [world-systems analysis] of economism," Forte concludes, "but only with less and less justification" ("Globalization and World-Systems Analysis: Toward New Paradigms of a Geo-Historical Social Anthropology," Review 21, no. 1 [1998]: 29-99, quote on 65).

${ }^{15}$ Carlos Alberto Torres, "Globalization and Comparative Education in the World System," Comparative Education Review 45 (November 2001): iii-x, quote on ix.
} 
CLAYTON

Dependency Theory

World-systems analysis both builds on and critiques dependency theory, which itself responded to modernization theory, so it is with modernization theory that I begin. Modernization theory or "developmentalism" presents the world as a collection of autonomous nations, operating independently of one another, in which leaders can experiment freely with policies in an effort to achieve development objectives. This perspective found perhaps its strongest voice in Walt Rostow's The Stages of Economic Growth ${ }^{16}$ In this text, Rostow articulates his classic stage theory for capitalist economic development. Traditional societies - primitive, feudal, precapitalist-begin their transition to capitalism, Rostow argues, having met certain "preconditions for take-off." Reaching a critical precondition mass, economic "take-off" occurs, as it did in England, France, the United States, and other nations in generations past, and countries proceed apace through "drive to technological maturity" and finally to "high mass consumption." According to the tenets of modernization theory, all nations can follow the pattern set by advanced countries and develop toward the standard of living enjoyed in Western Europe and North America. ${ }^{17}$

Dependency theory arose in the 1960s, largely among Latin American scholars, as a means of explaining why "modernization" or "development" had not happened everywhere. Adumbrated by Raúl Prebisch's The Economic Development of Latin America and Its Principal Problems and Paul Baran's The Political Economy of Growth, and elaborated in such volumes as Dependency and Development in Latin America, Capitalism and Underdevelopment in Latin America, and Nationalism and Capitalism in Peru, the dependentistas grappled with what appeared to be static and inequitable international capitalist relations. ${ }^{18}$ Rejecting the notion of the world as a group of autonomous nations, these scholars suggested that the world comprised a single, capitalist, economic system; in this system, they argued, different countries perform different roles or functions. The idea of a single division of labor within a single worldeconomy represents the most important contribution of dependency theory:

\footnotetext{
${ }^{16}$ Walt Whitman Rostow, The Stages of Economic Growth: A Non-Communist Manifesto (Cambridge: Cambridge University Press, 1960).

${ }^{17}$ On modernization theory, also see Daniel Lerner, The Passing of Traditional Society: Modernizing the Middle East (New York: Free Press, 1958); Walt Whitman Rostow, Rich Countries and Poor Countries: Reflections on the Past, Lessons for the Future (Boulder, Colo.: Westview, 1987). For a contemporary application, see William Easterly, The Elusive Quest for Growth: Economists' Adventures and Misadventures in the Tropics (Cambridge, Mass.: MIT Press, 2002).

${ }^{18}$ Respectively, Raúl Prebisch, The Economic Development of Latin America and Its Principal Problems (Lake Success, N.Y.: United Nations Department of Economic Affairs, 1950); Paul Baran, The Political Economy of Growth (New York: Monthly Review Press, 1957); Fernando Henrique Cardoso and Enzo Faletto, Dependency and Development in Latin America, trans. Marjory Mattingly Urquidi (Berkeley: University of California Press, 1979); Andre Gunder Frank, Capitalism and Underdevelopment in Latin America: Historical Studies of Chile and Brazil (New York: Monthly Review Press, 1967); Aníbal Quijano, Nationalism and Capitalism in Peru: A Study in Neo-Imperialism, trans. Helen Lane (New York: Monthly Review Press, 1971).
} 
for scholars and national policy makers who subscribed to this perspective, the world was not a collection of independent, boundaried nations, but an integrated, international, system-the world-system. ${ }^{19}$

Dependency theorists explained the roles within the international division of labor as geographical binaries: the "periphery" or "satellite," where raw materials are grown or mined, and the "core" or "metropolis," where value-added manufacturing or other processing takes place. For all intents and purposes, dependency theorists projected Marx's vision of classed society to the international level. Thus, in both dependency theory and orthodox Marxism a particular group (the core or the capitalist class) is seen as controlling the means of and extracting the surplus from production; a second group (the periphery or the proletarian class) is seen as having limited control over its labor and as receiving minimal compensation for it. Similarly, dependency theorists extended the structural influence Marx ascribed to the capitalist mode of production. Even as Marx argued that the emergence of capitalism influenced social organization by encouraging peasants to become wage earners, so too did dependency theorists suggest that the expansion of capitalism had initiated a new form of proletarianization-in this case, where countries in one part of the world (the periphery) had been proletarianized in the service of countries in another (the core).$^{20}$

That core and periphery countries exist together within a single worldsystem suggests an entirely different perspective about the potential for change than that suggested by modernization theorists. For Rostow, nations could advance or develop under the right conditions; Rostow worked in both the Kennedy and Johnson administrations in assisting developing nations toward these conditions. Dependency theorists, on the other hand, saw few possibilities for periphery nations to change their status as proletarians within the world-economy. Frank described this immutable status as "underdevelopment," coining the term as a foil to modernization theory's central tenet. For Frank and others, underdevelopment had been purposefully engineered by core nations as a means of maintaining the economic dependencies emphasized in the very name of their theoretical contribution. In Chile, he

\footnotetext{
${ }^{19}$ Note that I use the term "international" purposefully here, to reflect dependency theorists' focus on relations "between nations" in the world-system. For good histories of dependency theory, see Magnus Blomström and Björn Hettne, Development Theory in Transition: The Dependency Debate and Beyond (London: Zed, 1984); Andre Gunder Frank, "The Underdevelopment of Development," in The Underdevelopment of Development: Essays in Honor of Andre Gunder Frank, ed. Sing Chew and Robert Denemark (Thousand Oaks, Calif.: Sage, 1996), pp. 17-55; Jorge Larrain, Theories of Development: Capitalism, Colonialism and Dependency (Cambridge: Polity Press, 1989).

${ }^{20}$ In fact, dependency theorists depart from Marx in several ways. Beyond possibly assigning greater importance to exchange relations, dependency theorists also disagree with Marx about capitalism commencing with "primitive accumulation." On these issues, see Sing Chew and Robert Denemark, "On Development and Underdevelopment," in Chew and Denemark, eds., pp. 1-16.
} 
concluded as an example, "underdevelopment . . . is the necessary product of four centuries of . . . capitalism itself." ${ }^{21}$

\section{World-Systems Analysis}

With the idea of a single world-economy and a single division of labor, dependency theorists introduced one of the central tenets of globalization analysis 3 decades before this latter field coalesced. It is true that for the most part they understood this division of labor in national terms-as illustrated in the title of one dependency discussion, The Wealth of Some Nationsbut I want to be careful not to overstate the case. ${ }^{22}$ Indeed, there were "as many 'dependency theories' as there were dependency theorists," and several theorists demonstrated a strong early tendency to look beyond nations in their analysis. ${ }^{23}$ Osvaldo Sunkel, for example, proposed a model based on "transnational integration and national disintegration," where the transnational core of the world capitalist system overlapped the boundaries of both core and periphery nations. ${ }^{24}$ Frank demonstrated concern that nations not be analyzed monolithically by conceptualizing the world-system as a chain linking workers and capitalists at multiple levels. This "whole chain of constellations of metropoles and satellites relates all parts of the whole system," he wrote in an article originally published in 1966, "from its metropolitan center in Europe or the United States to the farthest outposts in the Latin American countryside." ${ }^{25}$

Nevertheless, it was not with dependency theory that scholars interested in the integrated world-economy moved substantially beyond state centrism. Rather, this transition began with the publication of The Modern World-System I: Capitalist Agriculture and the Origins of the European World-Economy in the Sixteenth Century by Immanuel Wallerstein in 1974; Wallerstein followed this contribution with The Modern World-System II: Mercantilism and the Consolidation of the European World Economy, 1600-1750; The Modern World-System III: The Second Great Expansion of the Capitalist World-Economy; and many other books. ${ }^{26}$ Building on the contributions of Frank and other dependency theorists, with

\footnotetext{
${ }^{21}$ Frank, Capitalism, p. 3.

${ }^{22}$ Malcolm Caldwell, The Wealth of Some Nations (London: Zed, 1977).

${ }^{23}$ Blomström and Hettne, p. 91.

${ }^{24}$ Osvaldo Sunkel, "Transnational Capitalism and National Disintegration in Latin America," Social and Economic Studies 22 (March 1973): 132-76, quote on 163.

${ }^{25}$ Andre Gunder Frank, "The Development of Underdevelopment," in The Political Economy of Development and Underdevelopment, ed. Charles Wilber (New York: Random House, 1979), pp. 103-13, quote on p. 105. Originally published as Andre Gunder Frank, "The Development of Underdevelopment," Monthlv Review 19, no. 4 (1966): 17-31.

${ }^{26}$ Immanuel Wallerstein, The Modern World-System I: Capitalist Agriculture and the Origins of the European World-Economy in the Sixteenth Century (New York: Academic Press, 1974), The Modern World-System II: Mercantilism and the Consolidation of the European World Economy, 1600-1750 (New York: Academic Press, 1980), and The Modern World-System III: The Second Great Expansion of the Capitalist World-Economy (New York: Academic Press, 1989)
} 
them on Marx, and also on Fernand Braudel's groundbreaking explorations of the historical development of capitalism within the Annales tradition, ${ }^{27}$ Wallerstein suggests a substantially more complex understanding of capital flows and capitalist relations in the world than that presented in dependency theory. The theoretical contribution he initiated-world-systems analysisnow comprises a substantial body of literature, pursued in hundreds of volumes and several journals dedicated to the subject, notably the Journal of World-Systems Research and Review, the journal of the Fernand Braudel Center.

As inspired by Wallerstein and further developed by Terence Hopkins, Christopher Chase-Dunn, and scores of other scholars (many of whom have been associated with Wallerstein's Fernand Braudel Center for the Study of Economics, Historical Systems, and Civilizations at the State University of New York at Binghamton), world-systems analysis shares with dependency theory the idea of a single world-economy and a single, axial division of labor (though Wallerstein suggests the status of "semiperiphery" to augment the previous dichotomous structure of the world-system). These fundamentals emerge frequently in Wallerstein's writing, as the following example from The Politics of the World-Economy illustrates: "The capitalist world-economy has operated via a social relationship called capital/labor, in which the surplus created by direct producers has been appropriated by others . . . by virtue of the fact that the appropriators control the 'capital' and that their 'rights' to the surplus are legally guaranteed. . . . Once surplus-value has been extracted, it has yet to be 'distributed' among a network of beneficiaries. The . . . structure of the world-economy permits $\mathrm{a}[\mathrm{n}]$ unequal exchange of goods and services, such that much of the surplus-value extracted in the peripheral zones of the world-economy is transferred to the core zones." 28

The historical view that Wallerstein and other scholars take, however, suggests the first of two important innovations in relation to dependency theory. Wallerstein himself argues that the expansion of capitalism began in Western Europe in the "long sixteenth century" (1450-1640), a phrase he borrows from Braudel. As he details in The Modern World-System I, on the basis of impressive historical data, this period saw significant commodification of land and a form of proletarianization he labels the "second serfdom," by which he means "slavery [and] coerced cash-crop production." ${ }^{29}$ By the dawn of the Industrial Revolution-when most economic historians understand the expansion of capitalism to have begun-Wallerstein argues that "agri-

\footnotetext{
${ }^{27}$ For example, Fernand Braudel, Capitalism and Material Life, 1400-1800, trans. Miriam Kochan (New York: Harper \& Row, 1973).

${ }^{28}$ Immanuel Wallerstein, The Politics of the World-Economy: The States, the Movements, and the Civilizations (Cambridge: Cambridge University Press, 1984), p. 15.

${ }^{29}$ Immanuel Wallerstein, The Capitalist World-Economy (Cambridge: Cambridge University Press, 1979), p. 17.
} 
cultural capitalism" was already operating at the world level and that the trichotomous structure of the modern world-system had already solidified. ${ }^{30}$

Studying capitalism over what Braudel termed "la longue durée" allows world-systems scholars to track flows and ebbs in the world-economy-and, importantly, to identify the fluidity of economic relations. Most agree, for instance, that nearly the entire globe had been incorporated into the worldeconomy by the turn of the twentieth century; economic integration or the "expan[sion] and intensif[ication of] links" within the world-economy has continued since that time, albeit interrupted by periods of war and protectionism. ${ }^{31}$ Historically, geographical areas entered the world-economy in the periphery. While many have been unable to alter this status (much of Latin America and Africa, e.g.), Japan quickly graduated to the semiperiphery and, by about 1970, the core. The United Provinces (Holland), the United Kingdom, and the United States all advanced to core status from previous positions in the periphery or semiperiphery. For Wallerstein, these three polities distinguish themselves as "hegemons," having accomplished "hegemony" over virtually the entire world-economy (the United Provinces in the mid-seventeenth century, the United Kingdom in the mid-nineteenth century, and the United States in the mid-twentieth century), though they all subsequently declined relative to rising competitors. ${ }^{32}$

Russia and the Soviet Union provide an interesting example of status change in the world-system. Wallerstein and other scholars reject the notion that during the cold war the communist bloc constituted a "socialist" worldeconomy that existed independently from the capitalist world-economy. ${ }^{33}$ According to Wallerstein, Russia entered the capitalist world-system in the nineteenth century with semiperiphery status, owing to "the strength of its state machinery (including its army) and the degree of industrialization already achieved in the eighteenth century." By the turn of the twentieth century, however, penetration of foreign capital (among other factors) threatened this position, and Russia "began on a decline towards a peripheral status." Wallerstein understands the October Revolution as responding to this economic crisis. Embarking on the communist path, Lenin was able to partially withdraw Russia from the world-economy; in the subsequent protectionist period, Soviet leaders succeeded in reversing the trends toward peripheralization to the extent that, at the end of the Second World War,

${ }^{30}$ Wallerstein, Capitalist, p. 16.

${ }^{31}$ Boswell and Chase-Dunn, p. 210 (n. 2 above).

${ }^{32}$ Immanuel Wallerstein, "The Three Instances of Hegemony in the History of the Capitalist WorldEconomy," International Journal of Comparative Sociology 24 (January-April 1983): 100-108. Wallerstein uses "hegemony" here in a Leninist sense of the word, meaning "power" or "preponderance of control" in the world-economy.

${ }^{33}$ Notably, Boswell and Chase-Dunn; Christopher Chase-Dunn, "Socialist States in the Capitalist World-Economy," Social Problems 27 (June 1980): 505-25, and Socialist States in the World-System (Beverly Hills, Calif:: Sage, 1982). 
they could "reinstate [the new Union in the capitalist world-system] as a very strong member of the semiperiphery [that] could begin to seek full core status." ${ }^{34}$

The point in relating the histories of Russia/Soviet Union, Japan, the United Provinces, and other polities is not to illustrate the trajectory of specific regions or nations in the world-system but to introduce the possibilities for movement that scholars see within that system. While dependency theorists saw economic relations as immutable- "stagnationist," to use Jorge Larrain's word, ${ }^{35}$ world-systems scholars see them as changing, shifting, effervescent. If dependency theorists privileged particular capitalist relations in their analyses (U.S. neocolonial domination of Latin America, e.g.), worldsystems scholars focus on capitalism itself, as it acts upon and is mediated by variable and impermanent political entities. Studying the world-economy temporally, Wallerstein and others induce themes from the sweep of history that reaffirm the essentials of dependency theory (the expropriation and movement of capital, the asymmetrical structure of the world-system, etc.), while illustrating the inaccuracy of the static relations that emerge in that earlier body of literature. In so doing, world-systems analysts achieve greater flexibility to describe "center-periphery structures that are unstable over time" and that "expand, contract, and sometimes collapse as regular manifestations of shifts in the locus of accumulation." 36

The idea of the world-economy acting upon and being mediated by variable and impermanent political entities introduces the second major innovation of world-systems analysis. In fact, scholars go considerably farther than delinking the world-economy from particular national groupings: they delink it from the system of national political organization entirely. As Wallerstein explains, the world-economy is overlain by a "political superstructure" of nations or states, even as the straight lines of national boundary may overlie a topographical map. ${ }^{37}$ While there is clear correspondence between nations and the tripartite structure of the world-economy (Japan, Mexico, and Zaire have core, semiperiphery, and periphery status generally and respectively), world-systems scholars see this association as imperfect at best. "Political units are not coextensive with the boundaries of the market economy," Wallerstein

${ }^{34}$ Wallerstein, Capitalist, pp. 27, 31.

${ }^{35}$ Larrain (n. 19 above), p. 146. This does not mean that dependency theorists saw no possibility of altering dependency relations. Rather, seeing change within the world-economy as an impossibility, many dependency theorists advocated the withdrawal or "de-linking" of underdeveloped countries from that economy. Change would be possible once underdeveloped countries had escaped the "chain of constellations of metropoles and satellites" described by Frank ("Development" [n. 25 above], p. 105). As Frank concluded in the same contribution, "underdeveloped countries' . . . economic development can now occur only independently of . . . metropolitan countries" (p. 104).

${ }^{36}$ Barry Gills and Andre Gunder Frank, "The Cumulation of Accumulation," in their The World System: Five Hundred Years or Five Thousand? (London: Routledge, 1993), pp. 81-114, quote on pp. 107-8.

${ }^{37}$ Wallerstein, Politics, p. 14. 
argues. ${ }^{38}$ "Economic decisions are primarily oriented to an arena distinct from the bounded territorial control points where state power resides," echoes Walter Goldfrank..$^{39}$ The "economy-polity contradiction" or "antinomy" that these scholars identify stands as a central feature of world-systems analysis. ${ }^{40}$ For Wallerstein and others, capital in the world-system does not flow from nation to nation-from dependent, periphery Chile to dominant, core United States, for example-but among zones that overlap national boundaries in complex, discontinuous ways. ${ }^{41}$

This does not mean that polities serve no function in the world-system, however. Historically, it has been at the national level that laws are madeand enforced-about economic practices, international alliances, trade barriers, and so on; recently, some states have ceded at least some authority to supranational bodies like the North American Free Trade Association and the World Trade Organization. For world-systems scholars, economic actors maneuver through the political channels provided by nations and supranational institutions to achieve both specific and general goals (expanding into new markets, eliminating or erecting tariffs, enabling the free movement of capital while inhibiting the movement of labor, among others). As Wallerstein comments, such actors (individuals, families, groups, companies, transnational corporations, etc.) "pursue their economic interests within a single world market while seeking to distort this market for their benefit by organizing to exert influence on states [and supranational organizations], some of which are far more powerful than others." ${ }^{42}$

The fact that world-systems scholars frequently speak of specific polities can be misleading. Consider Boswell and Chase-Dunn's analysis of recent world economic shifts. Examining developments in the world-economy in the last several decades, these scholars comment on the "steady downward trend of the U.S. share" of the world-economy in relation to Japan, Great Britain, Germany, and France. "If we add the 1994 [world] GDP shares of the countries brought together in the European Union," they conclude, "they have a combined share of 19 percent, compared to 20 percent for the United States [and about 10 percent for Japan]. ${ }^{43}$ Reading this statement in isola-

${ }^{38}$ Wallerstein, Capitalist, p. 66.

${ }^{39}$ Walter Goldfrank, "Paradigm Regained? The Rules of Wallerstein's World-System Method," Lournal of World-Systems Research 6 (Summer/Fall 2000): 150-95, quote on 176, http://www.jwsr.ucr.edu/ archive/vol6/number2/pdf/jwsr-v6n2-goldfrank.pdf.

${ }^{40}$ Terence Hopkins and Immanuel Wallerstein, World-Systems Analysis: Theory and Methodology (Beverly Hills, Calif.: Sage, 1982), p. 58; Wallerstein, Capitalist (n. 29 above), p. 275.

${ }^{41}$ Among other things, the economy-polity contradiction accounts for the presence of periphery areas in nations with generally core status (Appalachia in the United States, e.g.) and core areas in countries with generally periphery status (Guangzhou in the People's Republic of China, e.g.).

${ }^{42}$ Wallerstein, Capitalist, p. 25. Chase-Dunn concludes more simply that polities "are utilized by the [economic actors] that control them to expropriate shares of the world surplus product" (Socialist States, p. 506).

${ }^{43}$ Boswell and Chase-Dunn (n. 2 above), pp. 40-41. 
tion, we might think that the authors endorsed a view of the world-system in which political and economic boundaries were coterminous. Reading this statement with the economy-policy contradiction in mind, on the other hand, we recognize that Boswell and Chase-Dunn are using nations (and supranational organizations) here as a shorthand. More specifically, for worldsystems scholars, the United States and the European Union do not themselves control a share of the world-economy, but provide a political home to those economic actors who, when aggregated on the basis of their national and supranational affiliations, do so.

Wallerstein himself speaks directly to those who may be confused by the references to nations and supranational groupings in world-systems analysis. The "unit of analysis [is the] world-system," he writes unequivocally, not the variable and impermanent political entities within it. ${ }^{44}$

\section{Historical (Dis)Continuity}

The focus on historical change in world-systems analysis represents the first of two important innovations over dependency theory toward a more complex understanding of the world. The dissociation of economic and political structures within the economy-polity contradiction represents the second. Significantly, this latter emphasis on capitalism as a world-level phenomenon neither contained nor defined by national boundaries anticipates the "borderless world" envisioned by some globalization theorists. ${ }^{45}$ Indeed, despite the fact that "Wallerstein himself rarely uses the word 'globalization," this other central tenet of globalization analysis is quite deeply embedded in world-systems analysis. ${ }^{46}$ If dependency theorists were interested in "international" relations (that is, relations between nations in the world-system), scholars beginning with Wallerstein examine "global" processes involving relations among groups that operate on a plane different than the system of national political organization.

As world-systems analysts and globalization scholars agree fundamentally about the single world-economy and the inaccuracy of nation-states as units of analysis, so too do they agree that something rather significant has happened in terms of economic integration in the last 30 years or so. Beyond a quantitative increase in the degree of global economic interconnectivity, scholars in both traditions argue that the world-economy has been "restruc-

\footnotetext{
${ }^{44}$ Immanuel Wallerstein, "The Rise and Future Demise of World-Systems Analysis," Review 21, no. 1 (1998): 103-12, quote on 106.

${ }^{45}$ For example, Kenichi Ohmae, The Borderless World: Power and Strategy in the Interlinked Economy (London: HarperCollins, 1990).

${ }^{46}$ Sklair, "Competing Conceptions" (n. 1 above), p. 150.
} 
tured" in important ways since the economic crises that began in the 1970 s. $^{47}$ Historically, economic actors have been associated with particular nations to the extent that their aggregated success and failure manifests as the rise and fall of those nations; that is to say, change in the world-system has historically occurred on economic and political planes simultaneously (if imperfectly), so that Wallerstein can speak with fair accuracy of the decline of the United Kingdom or the ascendancy of the United States. ${ }^{48}$ Since 1970, however, this relative harmony has begun to dissolve. More specifically, the economy-polity contradiction has widened as what scholars refer to as "separate national capitalist classes" have begun to integrate into a "global" or "transnational" capitalist "class" or "bourgeoisie." As a result of this restructuring, the worldeconomy has perceptibly separated from-begun to move against, rather than generally with-the system of national political organization.

Scholars differ about the degree to which a class "whose coordinates are no longer national" has formed.$^{49}$ Some see the transnational capitalist class as fully realized; national capitalist affiliation has virtually disappeared, for instance, in William Robinson and Jerry Harris's "division of the world into a global bourgeoisie [that is, the transnational capitalist class] and a global proletariat. ${ }^{" 50}$ Others describe an intermediate stage of development; Boswell and Chase-Dunn, for instance, conclude that "the world-system has now reached a point at which both the old interstate system based on separate national capitalist classes and new institutions representing the global interests of capitalists coexist and are powerful simultaneously. In this light, each country can be seen to have an important ruling-class fraction that is allied with the transnational capitalist class." ${ }^{51}$ Yet others discover only the beginnings of a transnational capitalist class; William Carroll and Colin Carson's empirical study, for example, points decisively toward the "persistence of national . . . power structures," despite their obvious inclination to conclude

\footnotetext{
${ }^{47}$ For a discussion of the quantitative increase in global economic interconnectivity, see Paul Ciccantell and Stephen Bunker, "International Inequality in the Age of Globalization:Japanese Economic Ascent and the Restructuring of the Capitalist World-Economy," Iournal of World-Systems Research 8 (Winter 2002): 62-98, http://www.jwsr.ucr.edu/archive/vol8/number1/pdf/jwsr-v8n1-ciccssntellbunker.pdf; Henk Overbeek and Kees van der Pijl, "Restructuring Capital and Restructuring Hegemony: NeoLiberalism and the Unmaking of the Post-war Order," in Restructuring Hegemony in the Global Political Economy: The Rise of Transnational Neo-Liberalism in the 1980s, ed. Henk Overbeek (London: Routledge, 1993), pp. 1-27. For good histories of these economic crises, which started with Nixon's canceling of the Bretton Woods agreement on stable currency exchange in 1967, ran through the oil crisis of the 1970 s, and included the debt crisis of the 1980s, see Philip McMichael, Development and Social Change: A Global Perspective (Thousand Oaks, Calif.: Pine Forge Press, 1996); Kees van der Pijl, "The Sovereignty of Capital Impaired: Social Forces and Codes of Conduct for Multinational Corporations," in Overbeek, ed., pp. 28-57.

${ }^{48}$ Wallerstein, "Three Instances" (n. 32 above).

${ }^{49}$ William Robinson and Jerry Harris, "Towards a Global Ruling Class? Globalization and the Transnational Capitalist Class," Science and Society 64 (Spring 2000): 11-54, quote on 14.

${ }^{50}$ Ibid., p. 17.

${ }^{51}$ Boswell and Chase-Dunn, p. 212.
} 
otherwise.${ }^{52}$ Whether they see it as advanced or inchoate, however, both worldsystems and globalization scholars accept the formation of a transnational capitalist class as integrally connected with-as "central to" or the "embodiment [and] expression of"-the contemporary process of economic globalization..$^{53}$

What they do not agree on is whether this formation and process connects with past trends and patterns. As I argued previously, world-systems analysts embrace history; in fact, it was in recognizing the sweep of history that Wallerstein began to separate world-systems analysis from dependency-oriented studies of world capitalism. Predictably, then, world-systems scholars take a long view on globalization. Boswell and Chase-Dunn provide one example. Surveying data on world trade and investment since 1800, these scholars discover three waves of economic "globalization": one in the last half of the nineteenth century, one in the first 3 decades of the twentieth, and one beginning in 1950 and continuing to the present. Comparing these periods of intensifying global economic integration, they argue that "the 1914 mark of trade globalization has only recently been surpassed" and that the worldeconomy had "nearly as high a level of 'investment globalization' in 1910 as it did in 1990. ${ }^{, 54}$ On the basis of such data, they frame contemporary economic globalization as "the acceleration of a cyclical trend that has long been in operation. ${ }^{.55}$

For some world-systems scholars, emergence of the transnational capitalist class signals the rise of a "new hegemony" (at least in Wallerstein's Leninist use of the word): it portends the ascendancy of the next capitalist fraction to control the world-economy. ${ }^{56}$ While recognizing that this would be the first group lacking national coordinates to attain hegemonic status, world-systems scholars do not recognize as fundamentally new the transnational capitalist class itself. According to Kees van der Pijl, for instance, a variety of groups

\footnotetext{
${ }^{52}$ William Carroll and Colin Carson, "Forging a New Hegemony? The Role of Transnational Policy Groups in the Network and Discourses of Global Corporate Governance," Lournal of WorldSystems Research 9 (Winter 2003): 67-102, quote on 90, http://www.jwsr.ucr.edu/archive/vol9/number1/pdf/jwsr

${ }^{53}$ Respectively, Robinson and Harris, p. 11; Carroll and Carson, p. 68.

${ }^{54}$ Boswell and Chase-Dunn (n. 2 above), pp. 211 and 33, respectively.

${ }^{55}$ Ibid., p. 34. For similar arguments, see many of the contributions in the special issue of the Journal of World-Systems Research on globalization (Susan Manning, ed., "Globalization," special issue, Journal of World-Systems Research 5 [Summer 1999], http://www.jwsr.ucr.edu/archive/vol5/number2/ index.shtml), notably Christopher Chase-Dunn, "Globalization: A World-Systems Perspective," http:// www.jwsr.ucr.edu/archive/vol5/number2/html/chase-dunn/index.shtml, 391-411, and Jonathan Friedman, "Indigenous Struggles and the Discreet Charm of the Bourgeoisie," http://www.jwsr.ucr.edu/ archive/vol5/number2/html/friedman/index.html, 187-216. Of course, world-systems scholars are not the only ones to note the historical continuity of contemporary globalization. Economists Kevin O'Rourke and Jeffrey Williamson make much the same argument in Globalization and History: The Evolution of a Nineteenth-Century Atlantic Economy (Cambridge, Mass.: MIT Press, 1999). Despite its title, the focus of this volume on poorer nations catching up with richer one illustrates the authors' modernization assumptions.

${ }^{56}$ Carroll and Carson, p. 67.
} 
"merge[d] different social elements into a bourgeois class at home and abroad" in the centuries before the twentieth. ${ }^{57}$ His dense historical analysis focuses in particular on Freemasonry; operating in England, France, and the United States in the eighteenth century, Freemasons pursued economic goals through networks that were "sprawling and spatially discontinuous" rather than geographically and nationally situated ${ }^{58}$ On the basis of this case study, van der Pijl concludes that "the transnationalization of the capitalist class," like the process of globalization with which it integrates, "is a manifest historical trend." ${ }^{59}$

There is a strong tendency among globalization scholars, on the other hand, to disconnect contemporary events from past history or trends. A large subset of those writing about the contemporary process of globalization seem simply to be unaware that the world-economy has been gradually integrating for hundreds of years and that previous epochs have seen significant global interconnectivity. Through their ahistorical, decontextualized discussions, these commentators imply that the contemporary era is fundamentally new and different than anything the world has seen before. By ignoring (or being ignorant of) the centuries-long process of global economic integration, they describe "a completely unintegrated world composed of autarchic national economies until some point (perhaps in the last few decades) [when] a completely global market for commodities and capital suddenly emerged." For them, globalization thus seems a "new, chronologically recent, process in which states are said to be no longer primary units of decision making, but are . . . only now . . . finding themselves located in a structure . . . called the "world market." ${ }^{61}$ With many world-systems scholars, I find lacking these "breathy discussions" of how the globalized world has leapt, fully formed, from the head of national autonomy. ${ }^{62}$ World-system analyst Janet AbuLughod and globalization scholars Gordon Smith and Moisés Naím push considerably farther in their evaluations. For them, such discussions are "global-babble" at best and "suffocating . . . nonsense and self-promotion" at worst. ${ }^{63}$ "Globaloney," adds Marxist scholar Ellen Meiksins Wood. ${ }^{64}$

\footnotetext{
${ }^{57}$ Kees van der Pijl, "Globalization or Class Society in Transition?" Science and Society 65 (Winter 2001-2): 492-500, quote on 495.

${ }^{58}$ Kees van der Pijl, Transnational Classes and International Relations (London: Routledge, 1998), p. 99.

${ }^{59}$ Van der Pijl, "Globalization,” p. 492.

${ }^{60}$ Chase-Dunn, "Globalization," p. 194.

${ }^{61}$ Wallerstein, "Rise and Future Demise" (n. 44 above), p. 107.

${ }^{62}$ Chase-Dunn, "Globalization," p. 192.

${ }^{63}$ Janet Abu-Lughod, "Going beyond the Global Babble," in Culture, Globalization and the WorldSystem: Contemporary Conditions for the Representation of Identity, ed. Anthony King (Binghamton: Department of Art and Art History, State University of New York at Binghamton), pp. 131-37, quote on p. 131; Smith and Naím (n. 5 above), p. 67.

${ }^{64}$ Ambalavaner Sivanandan and Ellen Meiksins Wood, "Globalization and Epochal Shifts: An Exchange," Monthlv Review 48 (February 1997): 19-32, quote on 21.
} 
Other globalization scholars, however, have read economic history carefully and have reached a deliberately different conclusion about contemporary global interconnectivity than world-systems analysts. Robinson and Harris, for example, concede that some statistics show the world-economy to be as highly integrated before the First World War as at the beginning of the twenty-first century. However, they caution, these figures represent "trade in goods and services between nationally-based production systems." ${ }^{\circ 5}$ Today, Robinson and Harris continue, the capitalist world-system has entered a new phase both embodied and expressed by the transnational capitalist class, which they conceptualize as a Gramscian "historic bloc" bringing together "transnational corporations and financial institutions, the elites that manage the supranational economic planning agencies, major forces in the dominant political parties, media conglomerates, and technocratic elites and state managers in both North and South." ${ }^{66}$ This phase-the "transnationalization of the production of goods and services," or more simply "globalization"—signals for Robinson and Harris a "qualitatively new epoch" in the development of the world capitalist system," not "merely a quantitative intensification of historical tendencies." ${ }^{\prime 67}$

A great many globalization scholars agree with Robinson and Harris that contemporary globalization departs the past both quantitatively and qualitatively. This belief emerges in the very language chosen by authors to describe the present era. "The transformation of the modern imperialist geography of the globe and the realization of the world market signal a passage within the capitalist mode of production," write Michael Hardt and Antonio Negri. ${ }^{68}$ A "new international division of labor has emerged [in] the period of upheaval we are living through," comment David Smith and József Böröcz. ${ }^{69}$ For Roger Burbach and William Robinson, contemporary globalization announces an "epochal shift [and] requires a change in our 'weltanschauung,' the very way we view the world." ${ }^{70}$ For these and other scholars, examining globalization as a historical phenomenon both obscures the important shifts or transformations of the last 30 years and at the same time weakens response to them. We cannot study this new era from the "very long-term perspective adopted by world-system theorists," Stefan Kipfer concludes, because that historical perspective "resists efforts to understand transnationalization as a qualitative

${ }^{65}$ Robinson and Harris (n. 49 above), p. 19.

${ }^{66}$ Ibid., p. 12.

${ }^{67}$ Ibid., pp. 19, 18, respectively.

${ }^{68}$ Hardt and Negri (n. 3 above), p. xiii; my emphases.

${ }^{69}$ David Smith and József Böröcz, "Introduction: Late Twentieth-Centurv Challenges for WorldSystem Analysis," in their A New World Order? Global Transformations in the Late Twentieth Century (Westport, Conn.: Praeger, 1995), pp. 1-15, quote on pp. 1, 2; my emphases.

${ }^{70}$ Burbach and Robinson (n. 14 above), p. 11; my emphases. 
transformation of capitalist development.""11 "Doubtless capitalism is capitalism is capitalism," begins Ambalavaner Sivanandan, "but the failure to distinguish between its different avatars freezes us in modes and forms of struggle which are effete and ineffectual." ${ }^{\text {2 }}$

\section{Relocating the Tension for Comparative Education}

Sklair is a strong advocate for globalization analysis-and more specifically for his own approach, which he terms the "global capitalism model." ${ }^{73}$ In globalization analysis, he argues, scholars accept that the whole world comprises a single economic system operated by a single division of labor; their theorization of this division of labor "strive[s] towards a concept of the 'global' that involves more than the relations between nation-states and state-centrist explanations of national economies competing against each other." ${ }^{\text {"74 }}$ It is in taking this view, Sklair concludes, that he and other globalization scholars advance beyond world-systems analysis, which he represents to the reader as "state-centrist" or "inter-nationally" oriented, unable to conceive of the world as anything other than a collection of competing states.

In thus positioning it, Sklair not only treats world-systems analysis simplistically, but he also misses the real point. As we have seen, both globalization and world-systems scholars build on the dependentistas' idea of a single, capitalist world-system, and both look beyond nations as units of analysis in this system. Referring to the centrally important disaggregation of economic and political planes that has oriented world-systems inquiry since long before there was such a thing as globalization analysis, William Martin argues that "world-systems scholars have [since the 1970s] insisted that capitalist accumulation has always been a global process, while political rule has been exercised through multiple, relationally constructed institutions. ${ }^{\prime 75}$ In fact, it is not in their conceptualization of the world or of the actors in it that worldsystems and globalization scholars part company, but in their view of history. While world-systems analysts understand the contemporary process of globalization, including the transnationalization of the capitalist class, as the continuation or acceleration of historical trends, many globalization scholars argue implicitly or explicitly that the world has entered a fundamentally new,

\footnotetext{
${ }^{71}$ Stefan Kipfer, "Globalization, Hegemony, and Political Conflict: The Case of Local Politics in Zurich, Switzerland," in Smith and Böröcz, eds., pp. 181-99, quote on p. 182.

${ }^{72}$ Sivanandan and Wood, p. 21.

${ }^{73}$ For a brief discussion, see Sklair, "Competing Conceptions" (n. 1 above), pp. 156-58, and also see The Transnational Capitalist Class (Oxford: Blackwell, 2001), and his Globalization: Capitalism and Its Alternatives (Oxford: Oxford University Press, 2002).

${ }^{74}$ Sklair, "Competing Conceptions," p. 156.

${ }^{75}$ William Martin, "Still Partners and Still Dissident after All These Years? Wallerstein, World Revolutions and the World-Systems Perspective," Journal of World-Svstems Research 6 (Summer/Fall 2000): 234-63, quote on 240, http://www.jwsr.ucr.edu/archive/vol6/number2/pdf/jwsr-v6n2-martin.pdf.
} 
qualitatively different age that neither extends history nor can be understood through historical inquiry. ${ }^{76}$

The real tension between world-systems and globalization scholars, then, lies in their views of history, not in the inter-national/global dichotomy named by Sklair. Perhaps not surprisingly, this tension emerges in discussions by comparative education scholars about contemporary globalization. Most commentators approach the phenomenon from the perspective of globalization analysis - that is, they seem to endorse the notion that globalization signals a new era in world history. "New or more complex patterns of the flow of the global economy are emerging," Holger Daun begins; within this context, "educational restructuring [has come] to be seen not as a reform among a series of reforms but as something different and more than a reform." "Globalization . . . is a phenomenon that comprises multiple and drastic changes in all areas of social life," argue Nelly Stromquist and Karen Monkman; in relation to education, "it is obvious that a rapid and sustained shift is occurring in the ways we learn and do things." ${ }^{\text {78 }}$ On the other hand, some scholars treat globalization as the continuation of historical trends, thus suggesting sympathies with world-systems analysis. In his introduction to The Dialectic of the Global and the Local, for instance, Robert Arnove discusses globalization inquiry in comparative education within the context of historical "shifts in paradigms and approaches to the field." Comparative education scholars should consider this contemporary focus a part of, rather than exclusive from, the "systematic, codified body of theory and knowledge" in the field, Arnove seems to conclude. ${ }^{79}$

Mining comparative education discussions for the assumptions of contributors does not always reveal certainty. Note, for instance, how Nicholas Burbules and Carlos Alberto Torres hedge with their statement: "We are in a new historical epoch, a new global order in which the old forms are not dead but the new forms are not yet fully formed." ${ }^{80}$ Raymond Morrow and Torres similarly acknowledge "that globalization has a long history, and yet we also are concerned with the novel features of more recent developments." ${ }^{11}$ Many comparative education scholars may be sympathetic with this cautious approach to globalization. On the one hand, they may agree that the contemporary world-economy differs qualitatively from previous eras. A trans-

\footnotetext{
${ }^{76}$ Holger Daun notes another difference between world-systems analysis and globalization analysis, namely, that the latter does "not assume that the world can necessarily be [characterized] as a system" ("Globalization and National Education Systems," in Daun, ed., pp. 1-31, quote on p. 1).

${ }^{77}$ Ibid., pp. 1, 22.

${ }^{78}$ Nelly Stromquist and Karen Monkman, "Defining Globalization and Assessing Its Implications on Knowledge and Education," in Stromquist and Monkman, eds., pp. 3-25; quotes on pp. 3, 11.

${ }^{79}$ Robert Arnove, "Reframing Comparative Education: The Dialectic of the Global and the Local," in Arnove and Torres, eds., pp. 1-23, quotes on pp. 16, 17.

${ }^{80}$ Burbules and Torres (n. 5 above), p. 12.

${ }^{81}$ Raymond Morrow and Carlos Alberto Torres, "The State Globalization, and Educational Policy," in Burbules and Torres, eds., pp. 27-56, quote on p. 28.
} 
national hegemony, for example, would be fundamentally different from previous national hegemonies, regardless of the steps taken toward it by Freemasons, whose transnationality van der Pijl readily points out was "fleeting and ephemeral" compared with their "comprehensive national bond(s)." ${ }^{\prime 2}$ On the other hand, they may hesitate to accept that globalization heralds the "end of history," to invoke Francis Fukuyama's famous dictum. ${ }^{83}$ After all, as Boswell and Chase-Dunn remind readers, scholars have announced the apocalypse in many periods of uncertainly, only later to be recognized as premature; as in many such times in world history, globalization scholars are today suggesting that "something has passed[, that] new forms have arisen[, and that] the old analytic tools and frames of reference" no longer obtain. ${ }^{84}$

But assessing or stating assumptions about the historical (dis)continuity of contemporary globalization also misses the point. Accordingly, the tension between world-systems analysis and globalization analysis that this essay has relocated frames what is in reality a debate about contemporary globalization that can be pushed forward through comparative education inquiry. Remembering Torres's admonition about the "lack of concrete empirical research" on globalization in comparative education, ${ }^{85}$ let me briefly discuss one area in which scholars may be able to advance this debate empirically. In the last few years, many researchers have examined the neoliberal agenda, that "sometimes uneasy and contradictory fusion" of ideas about how states should be organized in relation to the global economy. ${ }^{86}$ The case studies in Henk Overbeek's Restructuring Hegemony in the Global Political Economy: The Rise of Transnational Neo-Liberalism in the 1980s explore how the ideas contemporaneously associated with the deregulation and privatization initiatives in Reagan's America and Thatcher's England have come to be accepted around the world.$^{87}$ Numerous comparative education scholars have examined the "increasingly powerful discourses and policies of neo-liberalism" in education globally. ${ }^{88}$

\footnotetext{
${ }^{82}$ Van der Pijl, "Globalization" (n. 57 above), p. 495.

${ }^{83}$ Francis Fukuyama, The End of History and the Last Man (New York: Free Press, 1992).

${ }^{84}$ Boswell and Chase-Dunn (n. 2 above), p. 160. On this thesis, also see Jonathan Friedman, Cultural Identity and Global Process (London: Sage, 1994).

${ }^{85}$ Torres (n. 15 above), p. ix.

${ }^{86}$ Overbeek and van der Pijl (n. 47 above), p. 15.

${ }^{87}$ Overbeek, ed. (n. 47 above).

${ }^{88}$ Michael Apple, "Comparing Neo-Liberal Projects and Inequality in Education," Comparative Education 37 (November 2001): 409-23, quote on 409, and also see his "Between Neoliberalism and Neoconservatism: Education and Conservatism in a Global Age," in Burbules and Torres, eds., pp. 57-77; Richard Maclure, "NGOs and Education in Sub-Saharan Africa: Instruments of Hegemony or Surreptitious Resistance?" Education and Society 18, no. 2 (2000): 25-44; Karen Mundy, "Educational Multilateralism and World (Dis)Order," Comparative Education Review 42 (November 1998): 448-78; Daniel Schugurensky, "Higher Education Restructuring in the Era of Globalization: Toward a Heteronomous Model?" in Arnove and Torres, eds., pp. 283-304, and his "Syncretic Discourses, Hegemony Building, and Educational Reform," Education and Society 18, no. 2 (2000): 75-94.
} 
The general assumption of comparative education scholars seems to be that neoliberalism is a new ideological agenda associated with the new currents of contemporary globalization. Thus, Michael Apple presents neoliberalism as a new common sense for today's "time of radical social and educational change." ${ }^{89}$ For Daniel Schugurensky, neoliberalism has provided a "new discourse" for education since $1980 .{ }^{90}$ Karen Mundy associates the neoliberal agenda with a period of "fundamental change in both domestic and international orders" commencing about $1970 .{ }^{91}$ Beginning with this assumption of novelty, scholars then proceed to important discussions about neoliberalism, education, and globalization by grappling with questions such as How are educational institutions around the world mediating and ultimately advancing the neoliberal agenda? How is consent to this agenda influencing educational convergence or the global homogenization of educational policy and practice? How is consent to the neoliberal agenda facilitating the flow of capital in the world by way of educational commodification or preparation?

These are vital questions for comparative education scholars to ask about contemporary neoliberalism. But some who would argue that "neo" liberalism is not new might conclude that they are not the only questions worth asking. In his exploration of the three historical periods of hegemony in the modern world-system (see the "World-Systems Analysis" section, above), Wallerstein discovers a cluster of ideologies common to each. "Hegemonic powers during the period of their hegemony tended to be advocates of global 'liberalism,", he begins. "They came forward as defenders of the principle of the free flow of the factors of production (goods, capital, and labor) throughout the worldeconomy. They were hostile in general to mercantilist restrictions on trade, including the existence of overseas colonies for the stronger countries. They extended this liberalism to a generalized endorsement of liberal parliamentary institutions (and a concurrent distaste for political change by violent means), political restraints on the arbitrariness of bureaucratic power, and civil liberties." 92

Wallerstein's historical liberalism sounds remarkably like contemporary neoliberalism; Karl Polanyi's and Philip McMichael's explorations of nineteenth-century British market rule intimate a similar ideological correlation. ${ }^{93}$ In suggesting that the neoliberal agenda may extend a historical ideological trend, these scholars also suggest a productive approach for comparative

\footnotetext{
${ }^{89}$ Apple, "Comparing," p. 411.

${ }^{90}$ Schugurensky, "Higher Education Restructuring," p. 284.

${ }^{91}$ Mundy, p. 468.

${ }^{92}$ Wallerstein, "Three Instances" (n. 32 above), pp. 102-3.

${ }^{93}$ Karl Polanyi, The Great Transformation (New York: Rinehart \& Co., 1944); Philip McMichael, "World-Systems Analysis, Globalization, and Incorporated Comparison," Journal of World-Systems Research 6 (Fall/Winter 2000): 668-90, http://www.jwsr.ucr.edu/archive/vol6/number3/pdf/jwsr-v6n3 - mcmichael.pdf.
} 
education inquiry related to it. Consider how the addition of a historical dimension to the study of neoliberalism and education would expand the questions posed immediately above. We would ask not only how educational institutions around the world are today mediating and advancing the neoliberal agenda but how (or if) educational institutions mediated and advanced liberalism in centuries past, and how (or if) these successive clusters of ideologies differ. We would explore not only how consent to the neoliberal agenda is influencing global educational homogenization in the contemporary world, but how (or if) worldwide educational policy and practice converged under the influence of liberalism previously, and how (or if) successive periods of homogenization or convergence differ. We would examine not only how neoliberalism in education is today facilitating the movement of capital globally but how (or if) the ideas of liberalism promoted during previous hegemonies restructured education as a salable commodity or prepared recipients for global economic participation, and how (or if) the capital flows initiated in education differ in successive periods.

I have operationalized globalization here in relation to the neoliberal agenda. It is important to note, however, that a historical dimension could be added to comparative education inquiry concerning any of the phenomena that Robertson, Bonal, and Dale associate with globalization: the emergence of English as the global language, the global standardization of educational credentials or knowledge, the loss of national identity, and so on. ${ }^{94}$ Such multidimensional inquiry-about educational systems, policies, and practices; across regions, countries, locales; in relation to historical periods, epochs, or eras-will not only enrich Arnove's systematic, codified body of knowledge that comprises comparative education, and it will not only respond productively to Torres's call for more empirical research about globalization. ${ }^{95}$ Importantly, it will also provide a basis upon which comparative education scholars can contribute to the debate about historical (dis)continuity in the contemporary world. Accordingly, with data gathered through contemporary and historical empirical research, we will be able to speak with authority about the degree to which education in today's globalized world departs previous trends and directions, or extends them. Ultimately, when such comparative studies in education are aggregated with similar studies in other fields and reach some critical mass of profundity or persuasiveness, we may be able to resolve the debate that the relocated tension between world-systems analysis and globalization analysis illustrates and, finally, understand the world in which we live.

${ }^{94}$ Robertson, Bonal, and Dale (n. 9 above).

${ }^{95}$ Arnove, "Reframing" (n. 79 above); Torres (n. 15 above). 